\title{
Implementation of Sustainability Practices in the Hospitality Industry
}

\author{
Daniel E. Meeroff ${ }^{1}$ (D, P. D. Scarlatos ${ }^{1}$, Frederick Bloetscher ${ }^{1}$, Lanette Sobel$^{2}$ \\ ${ }^{1}$ Department of Civil, Environmental \& Geomatics Engineering, Florida Atlantic University, Boca Raton, FL, USA \\ ${ }^{2}$ Ecosante Consulting, LLC, Miami Beach, FL, USA \\ Email: dmeeroff@fau.edu,pscarlat@fau.edu,fbloetsc@fau.edu,Lanette@FertileEarthWormFarm.com
}

How to cite this paper: Meeroff, D. E., Scarlatos, P. D., Bloetscher, F., \& Sobel, L. (2020). Implementation of Sustainability Practices in the Hospitality Industry. Journal of Service Science and Management, 13, 189-208.

https://doi.org/10.4236/jssm.2020.132013

Received: January 6, 2020

Accepted: March 28, 2020

Published: March 31, 2020

Copyright (c) 2020 by author(s) and Scientific Research Publishing Inc. This work is licensed under the Creative Commons Attribution International License (CC BY 4.0).

http://creativecommons.org/licenses/by/4.0/

\begin{abstract}
The hospitality sector is becoming keenly aware of the benefits associated with implementing sustainability initiatives and optimizing its operations to encourage the tourism industry to conserve and protect natural resources, while at the same time maintaining guest expectations. The purpose of this study is to identify the factors that affect or influence the performance of specific practices to reduce waste, improve energy efficiency, conserve water, and improve air quality. This paper reports the environmental and economic performance as well as the social behavioral impacts of sustainability initiatives implemented by participating hotels. Examples illustrate policies and products that a lodging property can implement to generate environmental and economic benefits. Case studies provide insight into successful implementation of sustainability practices as well as future initiatives needed to maximize the positive impacts. A major takeaway was that many options are easily implementable in the hospitality sector. However, two issues work against meeting planned goals: 1) buy-in from management and 2) understanding the inter-relationships between operations and green lodging goals.
\end{abstract}

\section{Keywords}

Waste Minimization, Recycling, Water Conservation, Energy Efficiency, Indoor Air Quality, Communication, Lodging; Hospitality, Sustainable Practices

\section{Introduction}

The concept of "green" or "sustainable," with respect to the hospitality industry, has become a challenge for businesses attempting to cater to environmentally aware consumers (Wei et al, 2013; Chen et al., 2009; Han \& Kim, 2010). To ad- 
dress the fact that many lodging customers have become increasingly concerned about the environmental impact of the industry, a growing number of organizations have publicly emphasized their environmental commitment as a strategy to differentiate themselves from their competition (Jones \& Hillier, 2014; Pryce, 2001; Han et al., 2011; Han \& Kim, 2010). To understand how customers perceive these efforts, Han (2015) undertook a study to understand the formation of travelers' pro-environmental intentions in a green lodging context, finding that one could predict customer pro-environmental intention, a key concern for attracting certain travelers. Rahman and Reynolds (2019) confirmed that there is an influence on consumers when dealing with green lodging.

These same hotels have become more aware of the impact of their operations on the environment and the costs associated with that impact (Miao and Wei, 2013; Pizam, 2009). The United Nations estimates that buildings account for $40 \%$ of the world's carbon emissions (UN Environment Programme, 2009), and among the types of building uses, the hotel and lodging industry provides an intriguing opportunity because the occupants are temporary, and there is much inefficiency with respect to many aspects of the day-to-day operations such as washing towels and bedding, personal care product use, waste paper, heating and cooling, and food waste, among others. According to the World Travel and Tourism Council (2019), the private sector hospitality industry is responsible for $10.4 \%$ of global gross domestic product (GDP). In terms of resource consumption, the lodging industry for nearly $20 \%$ of the annual commercial water use (261 billion liters per year) in the United States (Energy Information Administration, 2017) generates $0.5-2.5$ million metric tons of solid waste annually (Abt Associates Inc., 2001), and uses the fifth most electricity within the commercial sector (Energy Information Administration, 2017). An average sized hotel purchases more products in one week than 100 families buy in an entire year (Scarinci \& Myers, 2014). As a result, the hospitality industry has a major opportunity to decrease the level of any environmental harm and become more eco-friendly (Han et al., 2011; Jones \& Hillier, 2014).

Green lodging establishments seek to minimize their harmful impact on the environment while addressing cost savings that might result (Han et al., 2010). Unlike conventional hotels, green hotels have monetary benefits to be gained by improving their environmental footprint. Among the benefits that hotel and chain managers have realized with their sustainability initiatives is increasing environmental stewardship and improving the health of guests and staff and potentially increasing revenue (due to higher average daily room rates, revenue per available room, and occupancy levels) from those looking for green hotels, while decreasing expenses (from lowered utility, waste, water use and maintenance costs), which create environmental benefits (Chan, 2005; Han et al., 2010; Manaktola \& Jauhari, 2007). The result is that some operators are desirous of implementing innovative green management guidelines strategies (Chen et al., 2009; Ham \& Han, 2013, Jones \& Hillier, 2014), but the question is which ones work and what is the potential market impact? This is a question that Jackson 
(2013) attempted to answer when noting that "best management practices in green lodging are dynamic, cost effective, innovative, stakeholder driven and environmentally sound technical and behavioral solutions that attempt to ameliorate or eliminate the negative environmental externalities associated with lodging operations." Examples included cool roofs, energy efficient windows and doors, occupancy sensors for HVAC, limiting hot water use in cleaning, LED lights, checking for water leaks and startup procedures for kitchens (Jackson, 2013). Graci and Dodds (2008) note that "cost savings; competitive advantage; employee loyalty; customer retention; regulatory compliance; risk management and social responsibility have been identified as the benefits to environmental commitment however with very limited discussion and proof in relation to the hotel industry." Graci and Dodds (2008) also note while there are numerous benefits to greening hotel operations, there remains a gap between attitude and action in the industry.

The lodging and hospitality industry in the US is large. Nationwide in the United States, the lodging industry comprised over 55,900 facilities with over 5.3 million rooms in 2018 and \$1.2 trillion in sales (Oxford Economics, 2019). Several local governments within the United States have developed programs to provide technical assistance and certification programs to help hotels achieve their environmental and efficiency goals. In the state of Florida, for example, the Florida Department of Environmental Protection's Florida Green Lodging Program (FGLP) establishes environmental guidelines for hotels and motels to conserve natural resources and prevent pollution by encouraging practices that focus on: 1) solid waste management and waste reduction, 2) water conservation, 3) energy efficiency, 4) clean air practices, and 5) communications. Designated properties have demonstrated their commitment to succeed in protecting natural resources while also saving money and garnering positive publicity. According to the Florida Department of Business and Professional Regulation (2019), as of 2018 there were 427,888 hotel, motel, and bed-and-breakfast rooms in Florida spread over 4796 properties. Resort condos and dwellings add another 1,297,320 units from 40,107 properties. All together, they serve about $126-131$ million guests annually, contributing over $\$ 24.3$ billion to the state economy in 2017 (Visit Florida, 2019). The lodging industry is responsible for generating $4 \%$ of the state's municipal solid waste per year, uses an estimated 625 million $\mathrm{kWh}$ of electricity, and consumes billions of gallons of water (Meeroff \& Scarlatos, 2007).

The purpose of this study was to identify factors that affect or influence the performance of specific practices to reduce waste, improve energy efficiency, conserve water, and improve air quality, and measure those impacts in specific hotel operations. In addition, the study aimed to understand the limitations that might exist for long-term implementation of green lodging practices, with an eye toward determining what steps might need to be taken to overcome those obstacles. The environmental and economic performance as well as the social behavioral impacts of conservation projects implemented by participating hotels 
will be explored to provide insight into successful implementation of sustainability practices as well as future conservation initiatives needed to maximize the positive impacts.

\section{Methodology}

Florida Atlantic University conducted the study using two medium-sized hotels in Miami Beach, FL (Miami-Dade County). The first property (Hotel A) is a 4-Star rated hotel with 104 rooms in one high-rise tower. The hotel is located in the historic art deco district on Collins Avenue with direct beach access. The hotel boasts a luxurious sundeck with private cabanas, a lagoon pool, a gourmet restaurant, and tropical gardens. The second property, Hotel B, has 105 rooms and suites in a motel-style configuration with two 2-story wings. Among the amenities of the property are a full-service spa, yoga facility, integrated wellness center, large and small meeting rooms, several outdoor meditation areas, a saltwater infinity pool, a heated waterfall massage, an aroma steam room, an outdoor mud lounge, a lobby bar, and a gourmet restaurant all overlooking Biscayne Bay.

The research team with input from the Florida Department of Environmental Protection (FDEP) analyzed the data gathered from site assessments, hotel operations, and staff interviews to make recommendations for implementing targeted and specific conservation efforts. Next, planning meetings were coordinated with vendor partners, technical partners, and support partners of the FGLP. These meetings outlined a menu of options that can be offered in the implementation plan tailored to each of the candidate hotel's specific needs. Then, the candidate hotels agreed upon a portfolio of conservation projects from the recommended project implementation plan to form a tailored action plan for monitoring progress and tracking performance measures. Implementation of the action plan included the following steps: 1) vendor fairs in which hotel personnel made time available to review vendors' products and services for potential implementation; 2) staff/employee training; and 3) installation, implementation and follow-up surveys and data collection.

As part of the site assessment portion of the study, both hotels were evaluated by members of the research team and the FDEP. In summary, both hotels were found to have some of the minimum requirements for the FGLP already existing, but the assessment team also identified several key opportunities for improvement as listed in Table 1.

Over the course of this pilot study, the performance of various implementation projects was evaluated. These included: 1) Aerator/spray nozzle fixture retrofits, 2) Laundry system upgrades, 3) Towel/linen reuse programs, 4) Cooling tower replacement, 5) Whole building water treatment, 6) Sub-metering, 7) Purchasing of Energy Star-rated appliances, 8) High efficiency lighting upgrades, 9) Green power, 10) Energy management systems, 11) Hazardous waste minimization, 12) Renovations to chemical storage facilities, 13) Recycling, 14) Indoor air quality monitoring, 15) Green cleaners, 16) MERV8 filters, 17) 
Table 1. Summary of existing pollution prevention practices and opportunities for improvement at both participating hotels.

\begin{tabular}{|c|c|c|c|c|}
\hline Category & $\begin{array}{l}\text { Hotel A } \\
\text { Existing }\end{array}$ & $\begin{array}{c}\text { Hotel A } \\
\text { Opportunities }\end{array}$ & $\begin{array}{l}\text { Hotel B } \\
\text { Existing }\end{array}$ & $\begin{array}{c}\text { Hotel B } \\
\text { Opportunities }\end{array}$ \\
\hline $\begin{array}{c}\text { Water } \\
\text { Conservation }\end{array}$ & $\begin{array}{l}\text { - Linen reuse } \\
\text { - } 1.6 \text { gpf toilets } \\
\text { - } 2.2 \text { gpm aerators } \\
\text { - Drip irrigation } \\
\text { - Xeriscaping } \\
\text { - Sub-metering }\end{array}$ & $\begin{array}{l}\text { - Towel reuse } \\
\text { - HVAC repair } \\
\text { - Showerhead replacement } \\
\text { - Pool cover } \\
\text { - Appliance replacement } \\
\text { - Leak detection program } \\
\text { - Pre-rinse spray washer }\end{array}$ & $\begin{array}{l}\text { - Linen/towel reuse } \\
\text { - } 2.2 \text { gpm aerators } \\
\text { - Drip irrigation } \\
\text { - Xeriscaping } \\
\text { - Sub-metering }\end{array}$ & $\begin{array}{l}\text { - Showerhead replacement } \\
\text { - Zero flush urinals } \\
\text { - Pool cover } \\
\text { - Appliance replacement } \\
\text { (dishwasher, } \\
\text { clothes washer) } \\
\text { - Exotic plant removal } \\
\text { - Leak detection program }\end{array}$ \\
\hline $\begin{array}{c}\text { Energy } \\
\text { Efficiency }\end{array}$ & $\begin{array}{ll}\text { - } & \text { Energy star appliances } \\
\text { - } & \text { Sensor lighting/dimmers } \\
\text { - } & \text { CFLs (back of house) } \\
\text { - } & \text { Double-paned windows }\end{array}$ & $\begin{array}{l}\text { - Appliance replacement } \\
\text { - HVAC replacement } \\
\text { - Programmable thermostats } \\
\text { - High efficiency lighting } \\
\text { - Window tinting }\end{array}$ & $\begin{array}{l}\text { - Energy star appliances } \\
\text { - Sensor lighting/dimmers } \\
\text { - CFLs (back of house) }\end{array}$ & $\begin{array}{l}\text { - Appliance replacement } \\
\text { - Programmable thermostats } \\
\text { - High efficiency lighting } \\
\text { - Window tinting } \\
\text { - Weather stripping }\end{array}$ \\
\hline $\begin{array}{c}\text { Waste } \\
\text { Reduction }\end{array}$ & $\begin{array}{l}\text { - Limited cardboard } \\
\text { recycling } \\
\text { - Reusable dinnerware }\end{array}$ & $\begin{array}{l}\text { - Hazardous waste recycling } \\
\text { Eco-purchasing ( } 30 \% \\
\text { post-consumer recycled } \\
\text { content) }\end{array}$ & $\begin{array}{l}\text { - Limited recycling } \\
\text { (back of house) } \\
\text { - Lease to buy options }\end{array}$ & $\begin{array}{l}\text { - Hazardous waste recycling } \\
\text { - Eco-purchasing } \\
\text { ( } 30 \% \text { post-consumer } \\
\text { recycled content) } \\
\text { - Refillable containers }\end{array}$ \\
\hline $\begin{array}{l}\text { Clean Air } \\
\text { Practices }\end{array}$ & - Eco-friendly cleaners & $\begin{array}{l}\text { - MERV8 filters } \\
\text { - Hazardous waste storage } \\
\text { - HVAC preventative } \\
\text { maintenance and } \\
\text { coil cleaning } \\
\text { - Microfiber cloths } \\
\text { - ETS Control }\end{array}$ & - Eco-friendly cleaners & $\begin{array}{l}\text { - } \text { MERV8 filters } \\
\text { - Hazardous waste storage } \\
\text { - } \text { HVAC preventative } \\
\text { maintenance and coil } \\
\text { cleaning } \\
\text { - Microfiber cloths } \\
\text { - ETS Control }\end{array}$ \\
\hline Communications & $\begin{array}{l}\text { - Linen reuse placards } \\
\text { - Newsletter }\end{array}$ & $\begin{array}{l}\text { - Additional signage } \\
\text { - Employee } \\
\text { training/rewards program }\end{array}$ & $\begin{array}{l}\text { - Linen/towel } \\
\text { reuse placards }\end{array}$ & $\begin{array}{l}\text { - Additional signage } \\
\text { - Employee } \\
\text { training/rewards program }\end{array}$ \\
\hline
\end{tabular}

Anti-Idling, 18) Purchase of low-emitting products, and 19) Communication steps.

A waste audit was conducted at Hotel B, but permission from the municipality was not initially granted for a similar audit for Hotel A because the waste storage area was in a highly visible location for pedestrians and tourists, and additional space on the grounds was not made available. To perform the audit, the researchers removed all solid waste from 3 of 4 dumpsters ( $2 \mathrm{yd}^{3}$ each), sorted the material into categories, weighed the material, and determined the composition of the waste by weight. One year later, permission was received to conduct a similar waste audit at Hotel B.

\section{Results and Discussion}

\subsection{Waste Reduction Practices}

In terms of waste reduction, both participating hotels offer recycling of paper, aluminum, cardboard, and plastic containers for staff and also for guests, an eco-purchasing program for consumables with post-consumer recycled content 
(office paper), bulk purchasing (cleaning chemical concentrates), reduced packaging, manufacturer take-back programs, ink/toner cartridge recycling, lease-to-buy options for office appliances, and refillable containers. In addition, both properties investigated the feasibility of community-scale composting although this was disallowed by local regulation.

The results of a waste audit conducted by the investigators are summarized in Figure 1. A total of 790 pounds ( $360 \mathrm{~kg}$ ) of material was collected, representing about $67 \%$ of the daily amount disposed of on a routine basis on a typical Monday during the slower period of the year (summer). This amounts to $16.3 \mathrm{lb}$ (7.4 $\mathrm{kg}$ ) per occupied room per day. Assuming single occupancy, this is much higher than the 7.53 - $10.97 \mathrm{lb}$ per person per day ( $3.41-4.98 \mathrm{~kg}$ per person per day) that is typical of Miami-Dade County (FDEP, 2010).

Recyclables were determined to account for $46 \%$ of the total solid waste found in the bins with the majority being comprised of cardboard and paper products as well as plastic but also an important contribution from glass. The two study hotels have access to single stream recycling services to reduce the on-site sorting requirements such that all recyclables can be placed in one container. Another important portion of the waste stream (36\%) was characterized as compostable, comprised of kitchen/food waste (20\%), leafy/yard waste (11\%), and soiled paper waste (5\%). The remaining amount accounted for only $18 \%$ of the total, signifying that if recycling and composting can be accomplished, the solid waste component can be reduced to less than one-fifth of the original capacity. Such an action would require changes to local regulations to allow a reduction of the minimum onsite waste storage capacity requirements set by the municipal code. According to previous pricing from the current waste hauler, the rental cost for municipal solid waste containers is approximately $3-4$ times higher than a comparable sized recycling container. By downsizing and optimizing the waste container situation, Hotel A saved $70 \%$ on its waste hauling services bill. It is estimated that since Hotel A began full scale recycling efforts over a 9-month
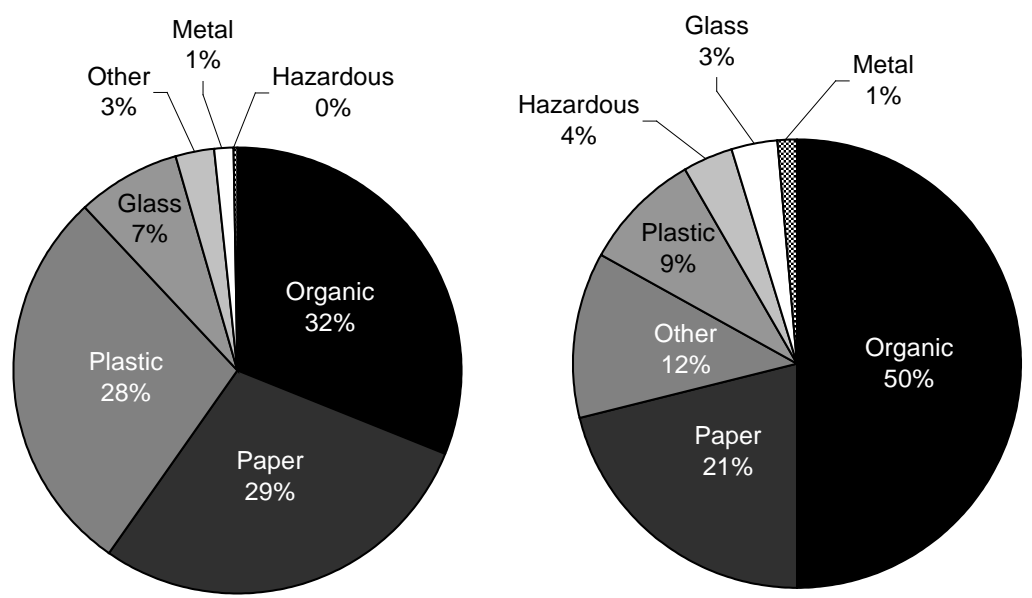

Figure 1. Results of a waste audit conducted pre-designation (left) and post-designation (right) showing the breakdown of waste composition at Hotel B, by weight. 
period, they were able to divert an estimated 594,770 lb/year $(269,740 \mathrm{~kg} /$ year $)$ from the landfill. Hotel B was able to divert an estimated 596,960 lb/year $(270,730 \mathrm{~kg} /$ year$)$ of waste from the landfill.

Nearly one year later, a waste audit was conducted at Hotel B after it received its green lodging designation. The researchers removed all solid waste from 3 of 4 dumpsters, sorted the material into categories, weighed the material, and determined the composition of the waste by weight (refer to Figure 1). An estimated $915.5 \mathrm{lb}(415 \mathrm{~kg})$ of material was generated by the property that day, which amounts to $12.5 \mathrm{lb}(5.7 \mathrm{~kg})$ per occupied room per day, which is down $23 \%$ from the prior waste audit (see Table 2). This is likely attributed to the success of the recycling program, which cut the percentage of recyclables wrongfully disposed in the solid waste almost in half from $46 \%$ to $24 \%$ of the total sent to the landfill. The non-recyclable, non-compostable component continued to comprise about $20 \%$ of the material, just as in the pre-designation waste audit.

Looking closely at the breakdown of waste materials, it was discovered that nearly $80 \%$ of the waste stream could be diverted from the landfill, eclipsing the $30 \%$ target mandated by the County at the time of the study and the $75 \%$ statewide recycling goal for 2020. A major component (56\%) is compostable (this includes the food scraps, leafy yard waste, and soiled paper products), but composting curbside collection was not yet available in the County, and on-site systems were not feasible due to space limitations and regulatory requirements for the participating hotels in this dense urban coastal environment. However, since more than half of the material in the waste stream was organic, this indicates that composting solutions should be pursued.

As a part of the second waste audit, the researchers pre-sorted the recyclables by department to assess the compliance level of hotel staff with regard to proper sorting for curbside single stream collection. Only about $17 \%$ of the material was improperly discarded in the single stream recyclable bins and compostable materials containers. These undesirables included hazardous materials, non-recyclable plastics, and other wastes like discarded clothes hangers, for example. When

Table 2. Summary of solid waste audit results for Hotel B compared to Miami-Dade County.

\begin{tabular}{cccc}
\hline Category & $\begin{array}{c}\text { Pre-Designation } \\
\text { (Hotel B) }\end{array}$ & $\begin{array}{c}\text { Post-Designation } \\
\text { (Hotel B) }\end{array}$ & $\begin{array}{c}\text { Miami-Dade } \\
\text { County 2010 Data }\end{array}$ \\
\hline Generation Rate (lb/capita/day) & 16.33 & 12.53 & 7.93 \\
Generation Rate (kg/capita/day) & 7.41 & 5.68 & 3.60 \\
\% Recyclable & $46 \%$ & $24 \%$ & $37 \%$ \\
\% Compostable & $36 \%$ & $56 \%$ & $49 \%$ \\
\% Non-Recyclable & $18 \%$ & $20 \%$ & $14 \%$ \\
Recycling Rate & $13 \%$ & $49 \%$ & $24 \%$ \\
\hline
\end{tabular}


Table 3. Breakdown of pre-sorted waste by department to determine non-compliance with recycling collection at Hotel $\mathrm{B}$ during the post-designation waste audit.

\begin{tabular}{cccc}
\hline Location & Non-Recyclables (lb) & Total Waste (lb) & Non-Compliance (\%) \\
\hline Engineering & $17.4^{\star}$ & 21.5 & $81 \%$ \\
F\&B & 7.8 & 18.3 & $43 \%$ \\
Pool & 7.6 & 29.3 & $26 \%$ \\
Spa & 1.4 & 7.0 & $20 \%$ \\
Kitchen/Restaurant & 1.2 & 113 & $1 \%$ \\
Housekeeping & $4.1^{* *}$ & 6.0 & $0 \%$ \\
Lobby/Front desk & 0 & 7 & $0 \%$ \\
Breezeway & 0 & 0.7 & $0 \%$ \\
Yard & 0 & 22.4 & $0 \%$ \\
Executive Offices & 0 & 8.0 & $0 \%$ \\
TOTAL & 39.4 & 233.2 & $17 \%$ \\
\hline
\end{tabular}

${ }^{*}$ Non-recyclables collected from engineering were construction/demolition waste items. ${ }^{*}$ Non-recyclables collected from housekeeping were biohazardous waste items.

the material in the outside bins (that was not pre-sorted at the source) was analyzed, $26 \%$ of the material that could have been recycled was improperly disposed of in the solid waste containers. The source of the greatest amount of non-recyclable material placed in the recycling containers was from the engineering department (see Table 3). To remedy this, the investigators recommended that the recycling containers be distinguished from the solid waste containers by color and/or labeling to help engineering personnel properly dispose of recyclables. A large portion of the non-recyclable materials generated in the engineering department were construction/demolition wastes that are reusable but need to be dealt with separately from the single stream recyclables.

The areas that generated the most non-recyclable waste included the food and beverage (F \& B) department, the outside pool area, and the spa facilities. For the pool area, the non-compliance percentage is understandable since there was only one bin for solid wastes near the pool exit, and the recycling container was located near the breezeway lobby (several hundred feet away from the pool). If the bins were co-located, perhaps compliance would improve, but this has been viewed as a "design issue" (which impacts the "guest experience"). The non-recyclables collected from the housekeeping stations turned out to be soiled linens containing blood or bodily fluids. This material is clearly non-recyclable, so the housekeeping compliance level is actually $100 \%$. For the other areas on the top of the list, better training of hotel staff might improve compliance.

\subsection{Water Use Efficiency Practices}

In terms of water conservation, an assessment was conducted over a 2.5-year period. Hotel A's average metered water consumption pre-implementation, was 
$456 \pm 71$ gpd $(1726 \pm 269$ lpd $)$ per occupied room. After implementing a towel/linen reuse training program, leak detection/identification, pre-rinse spray washers in the kitchen, irrigation system audit, and ultra low flow faucet aerators, the usage actually climbed to $513 \pm 105 \mathrm{gpd}(1942 \pm 397 \mathrm{lpd})$ per occupied room. Similarly, the effect of implementation on Hotel B is shown in Table 4. To provide context for these numbers, an average hotel is estimated to use approximately 210 - 225 gpd (795 - 852 lpd) per occupied room (DeOreo et al., 2016; Vickers, 2001).

For Hotel A, the decrease in efficiency of 57 gpd (217 lpd) per occupied room was attributed to the installation of a new roof mounted chiller and rehabilitation of the associated plumbing network. Unfortunately, at the beginning the study, Hotel A replaced the chiller unit. As the new chiller system incurred a number of installation issues and leaks, no useful data could be developed during the study period. For Hotel B, the decrease in efficiency of 131 gpd (496 lpd) per occupied room was attributed to leaks in the older plumbing network, some of which were discovered and repaired during the study period. The other main issue involved water waste associated with inefficiency of hot water supply.

Focusing on outdoor use, in the United States, it is estimated that 32 - 54 gpcd (121 - $204 \mathrm{lpcd})$ is consumed for outdoor water use and landscape irrigation (DeOreo et al. 2016). In Florida, irrigation usage is typically on the order of 50\% of the water use, especially during the dry season from (November to March). Both participating hotels sub-meter their irrigation and pool systems to reduce their water bill by avoiding sewer charges for outdoor water use. During the study period, Hotel A recorded its outdoor consumption as $67 \pm 41$ gpd (254 \pm $155 \mathrm{lpd})$ per occupied room, and Hotel B was $43 \pm 23 \mathrm{gpd}(163 \pm 87 \mathrm{lpd})$ per occupied room, both of which are higher than typical household irrigation water consumption. Hotel A saved nearly $\$ 722$ per month, and Hotel B saved $\$ 949$ per month, during the same period. Once the project was started, mandatory phase-1 water restrictions imposed by the South Florida Water Management District, mandated no more than twice per week irrigation between the hours of 12 a.m. to 10 a.m. and/or from 4 p.m. to 11:59 p.m. Hotel B's irrigation and pool distribution network also suffered from leaks during the project period and

Table 4. Summary of pre- and post-implementation water use for both participating hotels.

\begin{tabular}{|c|c|c|c|c|}
\hline Category & $\begin{array}{c}\text { Hotel A } \\
\text { Pre-Implementation }\end{array}$ & $\begin{array}{c}\text { Hotel A } \\
\text { Post-Implementation }\end{array}$ & $\begin{array}{c}\text { Hotel B } \\
\text { Pre-Implementation }\end{array}$ & $\begin{array}{c}\text { Hotel B } \\
\text { Post-Implementation }\end{array}$ \\
\hline $\begin{array}{l}\text { Average water use } \\
\text { per occupied room }\end{array}$ & $\begin{array}{c}456 \pm 71 \text { gpd } \\
(1726 \pm 269 \mathrm{lpd})\end{array}$ & $\begin{array}{c}513 \pm 105 \text { gpd } \\
(1942 \pm 397 \text { lpd })\end{array}$ & $\begin{array}{c}203 \pm 56 \text { gpd } \\
(768 \pm 212 \mathrm{lpd})\end{array}$ & $\begin{array}{c}334 \pm 85 \text { gpd } \\
(1264 \pm 322 \text { lpd })\end{array}$ \\
\hline $\begin{array}{l}\text { Average indoor use } \\
\text { per occupied room }\end{array}$ & $\begin{array}{c}390 \pm 67 \mathrm{gpd} \\
(1476 \pm 254 \mathrm{lpd})\end{array}$ & $\begin{array}{c}445 \pm 95 \text { gpd } \\
(1684 \pm 360 \mathrm{lpd})\end{array}$ & $\begin{array}{c}163 \pm 41 \text { gpd } \\
(617 \pm 155 \mathrm{lpd})\end{array}$ & $\begin{array}{c}285 \pm 90 \text { gpd } \\
(1079 \pm 341 \mathrm{lpd})\end{array}$ \\
\hline $\begin{array}{l}\text { Average outdoor use per } \\
\text { occupied room }\end{array}$ & $\begin{array}{c}66 \pm 71 \text { gpd } \\
(250 \pm 269 \mathrm{lpd})\end{array}$ & $\begin{array}{c}68 \pm 60 \text { gpd } \\
(257 \pm 227 \mathrm{lpd})\end{array}$ & $\begin{array}{c}40 \pm 24 \text { gpd } \\
(151 \pm 91 \mathrm{lpd})\end{array}$ & $\begin{array}{c}50 \pm 19 \text { gpd } \\
(189 \pm 72 \mathrm{lpd})\end{array}$ \\
\hline Annual water consumption & $\begin{array}{c}12.5 \mathrm{MG} \\
\left(47 \times 10^{6} \mathrm{~L}\right)\end{array}$ & $\begin{array}{c}14.1 \mathrm{MG} \\
\left(53 \times 10^{6} \mathrm{~L}\right)\end{array}$ & $\begin{array}{c}5.6 \mathrm{MG} \\
\left(21 \times 10^{6} \mathrm{~L}\right)\end{array}$ & $\begin{array}{c}9.2 \mathrm{MG} \\
\left(35 \times 10^{6} \mathrm{~L}\right)\end{array}$ \\
\hline
\end{tabular}


showed a net increase in water waste even with mandatory watering restrictions in place. As a result, the irrigation meters documented a $25 \%$ decrease in outdoor water usage for Hotel A over a 6-month time period.

To further explore the unexpected increases in indoor water consumption, the research team made several measurements of water usage throughout the property, as part of the monitoring program. Toilets were measured with a T5 flushometer, and showers and faucets were measured volumetrically with a graduate cylinder and a stopwatch. The results of the preliminary tests are found in Table 5. If all fixtures are replaced, the maximum water savings impact is achieved with faucet aerators. This led the hotels to investigate switching out the existing 2.2 - $2.5 \mathrm{gpm}(8.3$ - $9.5 \mathrm{lpm})$ faucet aerators. Miami-Dade County Water and Sewer Department supplied 54 of the $0.5 \mathrm{gpm}(1.9 \mathrm{lpm})$ aerators and three low-flow $1.6 \mathrm{gpm}(6.1 \mathrm{lpm})$ spray wash nozzles as a donation to each property. The hotel was initially concerned about the guest experience due to the loss of pressure and water volume. However, these fixtures were installed, and follow up measurements were conducted several months later, as summarized in Table 5. Unfortunately, in the public spaces, the water usage increased by $2.2 \mathrm{gpm}(8.3$ $\mathrm{lpm}$ ) due to theft and tampering/removal of the aerators by guests and staff. In the food services area, some of the new $0.5 \mathrm{gpm}(1.9 \mathrm{lpm})$ aerators were removed as well, essentially turning the previously $2.2 \mathrm{gpm}(8.3 \mathrm{lpm})$ faucets into $>4.0$ gpm $(15.1 \mathrm{lpm})$ faucets. The most beneficial impacts were found in the back of house areas, in which the aerators and leak repairs effectively changed the flow rate from $3.4 \mathrm{gpm}$ to $0.7 \mathrm{gpm}(12.9 \mathrm{lpm}$ to $2.6 \mathrm{lpm})$. If extrapolated to the entire hotel, this translates to a savings of $32.5 \mathrm{gpd}(123 \mathrm{lpd})$, assuming 1.0 minute per person per day, a usage factor of $25 \%$, and average hotel occupancy of 92.8 persons per day.

Follow up investigation revealed that the pool bartenders had removed several of the aerators, almost immediately after they had been installed because the

Table 5. Summary of water usage testing conducted at Hotel A.

\begin{tabular}{|c|c|c|c|c|c|c|c|}
\hline Location & $n$ & Toilets & Showers & Faucets (Pre) & Faucets (Post) & $\Delta \mathrm{Q}$ & Notes \\
\hline Public Spaces & 6 & $\begin{array}{c}1.9 \pm 0.4 \mathrm{gpm} \\
(7.2 \pm 1.5 \mathrm{lpm})\end{array}$ & $\mathrm{nr}$ & $\begin{array}{c}3.1 \pm 1.6 \mathrm{gpm} \\
(11.7 \pm 6.1 \mathrm{lpm})\end{array}$ & $\begin{array}{c}5.3 \pm 5.3 \mathrm{gpm} \\
(20.1 \pm 20.1 \mathrm{lpm})\end{array}$ & $\begin{array}{l}+2.2 \mathrm{gpm} \\
(+8.3 \mathrm{lpm})\end{array}$ & $\begin{array}{l}\text { Aerators were } \\
\text { tampered with }\end{array}$ \\
\hline Food Services & 9 & $\mathrm{n} / \mathrm{a}$ & $\mathrm{n} / \mathrm{a}$ & $\begin{array}{c}4.6 \pm 3.0 \mathrm{gpm} \\
(17.4 \pm 11.4 \mathrm{lpm})\end{array}$ & $\begin{array}{c}3.7 \pm 3.2 \mathrm{gpm} \\
(14.0 \pm 12.1 \mathrm{lpm})\end{array}$ & $\begin{array}{l}-0.9 \mathrm{gpm} \\
(-3.4 \mathrm{lpm})\end{array}$ & $\begin{array}{l}\text { Some aerators } \\
\text { were removed }\end{array}$ \\
\hline Back of House & 2 & $\begin{array}{l}1.7 \mathrm{gpm} \\
(6.4 \mathrm{lpm})\end{array}$ & $\mathrm{nr}$ & $\begin{array}{c}3.4 \pm 0.3 \mathrm{gpm} \\
(12.9 \pm 1.1 \mathrm{lpm})\end{array}$ & $\begin{array}{c}0.7 \pm 0.1 \mathrm{gpm} \\
(2.6 \pm 0.4 \mathrm{lpm})\end{array}$ & $\begin{array}{c}-2.7 \mathrm{gpm} \\
(-10.2 \mathrm{lpm})\end{array}$ & $\begin{array}{l}\text { Leaks also } \\
\text { repaired }\end{array}$ \\
\hline Guest Rooms & 5 & $\begin{array}{l}1.6 \mathrm{gpm} \\
(6.1 \mathrm{lpm})\end{array}$ & $\begin{array}{c}3.4 \pm 2.0 \mathrm{gpm} \\
(12.9 \pm 7.6 \mathrm{lpm})\end{array}$ & $\begin{array}{c}2.5 \pm 0.1 \mathrm{gpm} \\
(9.5 \pm 0.4 \mathrm{lpm})\end{array}$ & $\mathrm{nr}$ & $\mathrm{nr}$ & $\mathrm{n} / \mathrm{a}$ \\
\hline Average & - & $\begin{array}{l}1.8 \mathrm{gpm} \\
(6.8 \mathrm{gpm})\end{array}$ & $\begin{array}{c}3.4 \mathrm{gpm} \\
(12.9 \mathrm{lpm})\end{array}$ & $\begin{array}{c}3.7 \mathrm{gpm} \\
(14.0 \mathrm{lpm})\end{array}$ & $\mathrm{n} / \mathrm{a}$ & $\mathrm{n} / \mathrm{a}$ & $\mathrm{n} / \mathrm{a}$ \\
\hline Water Savings & - & $10 \% *$ & $36 \% * *$ & $640 \% * * *$ & $\mathrm{n} / \mathrm{a}$ & $\mathrm{n} / \mathrm{a}$ & $\mathrm{n} / \mathrm{a}$ \\
\hline
\end{tabular}

$\mathrm{n} / \mathrm{a}=$ not applicable. $\mathrm{nr}=$ not recorded. ${ }^{*}$ Assuming 5.1 flushes per day at an average of 1.6 gallons $(6.1$ liters) per flush (Vickers, 2001$) .{ }^{*}$ Assuming a total of 11.6 gallons (43.9 liters) per capita is used for showering at an average flow rate of $2.2 \mathrm{gpm}$ ( $8.3 \mathrm{lpm}$ ), or 5.3 minutes per capita per day for showering (Vickers, 2001). If compared to 2.0 gpm or $7.6 \mathrm{lpm}$ (41\% savings). ${ }^{\star \star *}$ Assuming 1 minute use per person per day, use factor of $25 \%$, hotel occupancy of 92.8 persons per day, compared to $0.5 \mathrm{gpm}(1.9 \mathrm{lpm})$. 
flow rate from was insufficient for rinsing pitchers and other bartending glassware and tools. This is particularly important when the bar is busy. A demonstration was performed for the bartenders to measure the amount of water coming out of the faucet with the $0.5 \mathrm{gpm}(1.9 \mathrm{lpm})$ aerator in place. A volume of $520 \mathrm{~mL}$ in 15 seconds $(0.5 \mathrm{gpm})$ was recorded. The bartenders were asked to estimate how much water would be collected with the aerator taken off. They predicted $4000 \mathrm{~mL}$ (4.2 gpm or $15.9 \mathrm{lpm}$ ). After removing the aerator completely, the volume of water generated in 15 seconds was again recorded, and the bartenders were surprised to discover that the final volume measured was $7860 \mathrm{~mL}$ (8.3 gpm or $31.4 \mathrm{lpm}$ ). In this case, it might be beneficial to install fan jet spray washers or foot pedal-operated spray nozzles in the pool bar area, so that bartenders have the speed of delivery necessary to complete their tasks quickly without wasting water.

\subsection{Energy Efficiency Practices}

Energy usage accounts for $60 \%-70 \%$ of a hotel's utility costs (Stipanuk, 2001; Nicholls \& Kang 2012). This includes lighting (30\% - 45\%), HVAC (25\% - 40\%), laundry and kitchen facilities (5\% - 10\%), and other operations (5\% - 10\%) (EIA 2017; Meeroff \& Scarlatos, 2007). The local electric utility and several vendor partners were contacted to assist in conducting energy audits and estimate potential savings from planned implementation projects. The natural gas service provider estimated a potential savings of $\$ 8000$ per year in unbundling the price of fuel and delivery. The power company conducted a lighting audit and projected an annual savings of $\$ 28,181$ and an additional $\$ 3996$ in pre-qualified incentives for switching to high efficiency lighting options in key areas of the hotel. The total number of lighting fixtures to be changed for each hotel is nearly 1100 . The initial costs for these retrofits were estimated at $\$ 13,740$ with a $3.6-5.8$ month payback at current monthly energy usage for each hotel. A vendor partner also conducted a lighting audit for Hotel A focusing on light-emitting diode lamps (LEDs). They estimated an annual savings of $\$ 183$ for the canopy area (10 lamps) with a 9-month payback period, \$2832 annual savings for the lounge area (48 lamps) with a 46-month payback period, and \$3066 annual savings for the hallways (96 lamps) with a 21 -month payback period.

In terms of electrical energy consumption, a 2.5-year assessment was conducted (see Table 6). Taking the average energy usage value pre-implementation,

Table 6. Summary of pre- and post-designation energy usage for both participating hotels.

\begin{tabular}{ccccc}
\hline Category & $\begin{array}{c}\text { Hotel A } \\
\text { Pre-Designation }\end{array}$ & $\begin{array}{c}\text { Hotel A } \\
\text { Post-Designation }\end{array}$ & $\begin{array}{c}\text { Hotel B } \\
\text { Pre-Designation }\end{array}$ & $\begin{array}{c}\text { Hotel B } \\
\text { Post-Designation }\end{array}$ \\
\hline Average electricity use & $\begin{array}{c}66.9 \pm 12.9 \mathrm{kWh} \\
\text { per occupied room }\end{array}$ & $\begin{array}{c}70.8 \pm 23.7 \mathrm{kWh} \\
\text { per occupied room }\end{array}$ & $\begin{array}{c}85.9 \pm 19.6 \mathrm{kWh} \\
\text { per occupied room }\end{array}$ & $\begin{array}{c}77.5 \pm 15.2 \mathrm{kWh} \\
\text { per occupied room }\end{array}$ \\
Annual energy consumption & 1.84 million $\mathrm{kWh}$ & 1.95 million $\mathrm{kWh}$ & 2.36 million kWh & 2.13 million kWh \\
Annual cost of energy & $\$ 194,000$ & $\$ 205,500$ & $\$ 239,000$ & $\$ 215,500$ \\
\hline
\end{tabular}


the amount of $\mathrm{kWh}$ consumed per occupied room was calculated. For Hotel A, this value was $66.9 \pm 12.9 \mathrm{kWh}$ per day, which corresponded to an annual usage of 1.84 million $\mathrm{kWh}$. After implementing back of the house high efficiency lighting replacements, Energy Star-rated appliance replacement purchasing program, reduced hot water demands from a towel/linen reuse program, leak detection/repair, pre-rinse spray washers in the kitchen, ultra low flow faucet aerators, and reduced irrigation pump operation, the usage actually climbed to $71 \pm 24$ $\mathrm{kWh}$ per day per occupied room, which corresponded to an annual usage of nearly 2 million $\mathrm{kWh}$ at an estimated annual cost of \$205,500 (computed from the data obtained for the 9-month period following implementation). The decrease in efficiency of $4 \mathrm{kWh}$ per occupied room per day, at an estimated 108,000 additional $\mathrm{kWh}$ per year was attributed to the installation of a new roof mounted chiller and rehabilitation of the associated plumbing network. The irrigation meter, which documented a $25 \%$ decrease in usage over the same period due to mandatory water restrictions imposed by the South Florida Water Management District, recorded reduced irrigation pump usage. For Hotel B, the energy efficiency improved by $10 \%$ or $8.4 \mathrm{kWh}$ per occupied room per day. This was attributed to the installation of a new energy efficient roof and high efficiency lighting combined with better air filtration, kitchen exhaust improvements, and a water leak detection program (hot water energy savings).

The research team identified 148 different appliances (not including HVAC equipment) and determined that the typical guest rooms have about 7 - 15 items each. Energy Star qualified equipment $(n=11)$ accounted for $8 \%$ of the total items surveyed. To increase this value, a policy for replacement of failed appliances with Energy Star equivalent items was recommended and instituted. Other energy saving programs implemented at both hotels included a purchase of Green Power credits, window film/tinting, and weather-stripping to increase air-tightness and reduce cooling costs.

Both participating hotels also conducted a comparison test with two energy management systems installed in the guest rooms. The first set of rooms used a card activated product, and the investigators measured the difference in energy consumption for the air conditioning unit between a managed room and a similar non-controlled room. The average difference was on the order of $116.8 \mathrm{kWh}$ per month (or $35 \%$ ). This translates to a monthly savings of $\$ 12$ per occupied room. Installation in every guest room would have a payback period of 24 months. Another finding of the pilot test was that air conditioning usage in the guest rooms comprised only $21 \%$ of the total energy consumption of the room. Typically, in the South Florida region, guest room air conditioning usage is expected to be $25 \%-40 \%$ of the total energy consumption (Meeroff \& Scarlatos 2008).

A second set of rooms used a product equipped with multiple occupancy sensors that allows the hotel to access the energy management system over the internet. The test room was found to have the air conditioning operating $24 \%$ of the time, and the control room had the air conditioning running nearly $50 \%$ of 
the time, averaged over several months. If this test is taken as representative, then the air conditioning usage may be cut in half by installing energy management systems.

\subsection{Clean Air Practices}

In terms of clean air practices, both hotels switched to environmentally-preferable cleaners, documented their preventative maintenance logs, installed high-efficiency MERV8 filters, instituted efficient set-backs for air conditioning units, and conducted indoor air quality testing. Hotel A switched its cleaning chemicals to eco-friendly alternatives for housekeeping, engineering, and kitchen services. Hotel B converted $100 \%$ of all housekeeping chemicals to third party certified eco-friendly cleaning products. The research team conducted interviews of the housekeeping directors on both properties to determine how they felt about the change in products. Both supervisors were extremely pleased with the results and were investigating changing out all of the cleaners in their inventories for eco-friendly versions (and for their personal use as well).

The research team with the assistance of a local health department conducted a pre-implementation air quality survey focusing on mold/mildew, relative humidity/temperature settings, moisture behind the drywall, particulates/dust, VOCs, carbon dioxide, and outside air ventilation rates. The results are summarized in Table 7.

For Hotel A, the thermal comfort values exceeded ASHRAE 62.1-2004 (acceptable summer temperature $=73^{\circ} \mathrm{F}-79^{\circ} \mathrm{F}$ and acceptable summer relative humidity $=30 \%-60 \%)$, but the ventilation and carbon dioxide measurements did meet ASHRAE 62.1-2004, Sections 4 - 7 (Q > 15 - $60 \mathrm{cfm}$ per person and $\left.\mathrm{CO}_{2}<1000 \mathrm{ppm}\right)$. Swab testing for mold was conducted in multiple areas of each hotel. One of the samples with the largest diversity of mold recorded during this round of testing was actually found in the second floor administrative offices of Hotel A near the general manager's office ( 9 types of mold and bacteria).

Table 7. Summary of indoor air quality surveys conducted at both participating hotels.

\begin{tabular}{|c|c|c|}
\hline IAQ Parameter & Hotel A & Hotel B \\
\hline Frequency of mold/mildew staining & $45 \%$ & $77 \%$ \\
\hline Frequency of leaks/stains & $36 \%$ & $31 \%$ \\
\hline Frequency of dust & $45 \%$ & $38 \%$ \\
\hline Total volatile organics (FID) & $41 \pm 28 \mathrm{ppm}$ & $19 \pm 16 \mathrm{ppm}$ \\
\hline Total volatile organics (PID) & $33 \pm 37 \mathrm{ppm}$ & $21 \pm 22 \mathrm{ppm}$ \\
\hline Average temperatures & $82^{\circ} \mathrm{F} \pm 5^{\circ} \mathrm{F}\left(28^{\circ} \mathrm{C} \pm 3^{\circ} \mathrm{C}\right)$ & $77^{\circ} \mathrm{F} \pm 3^{\circ} \mathrm{F}\left(25^{\circ} \mathrm{C} \pm 2^{\circ} \mathrm{C}\right)$ \\
\hline Average relative humidity & $58 \% \pm 10 \%$ & $57 \% \pm 10 \%$ \\
\hline Average ventilation rate per person & $\begin{array}{c}39 \mathrm{cfm} \pm 8 \mathrm{cfm} \\
\left(66 \mathrm{~m}^{3} / \mathrm{h} \pm 14 \mathrm{~m}^{3} / \mathrm{h}\right)\end{array}$ & $\begin{array}{c}26 \mathrm{cfm} / \pm 16 \mathrm{cfm} \\
\left(44 \mathrm{~m}^{3} / \mathrm{h} \pm 28 \mathrm{~m}^{3} / \mathrm{h}\right)\end{array}$ \\
\hline Carbon dioxide levels & $746 \mathrm{ppm} \pm 170 \mathrm{ppm}$ & $900 \mathrm{ppm} \pm 270 \mathrm{ppm}$ \\
\hline Largest mold diversity (location) & 9 colony types (Admin office) & 10 colony types (Salon) \\
\hline
\end{tabular}


Hotel A hired a professional indoor air quality monitoring contractor for follow up testing and recorded 720 total spores $/ \mathrm{m}^{3}$ in the second floor sales office compared to an outdoor baseline of 960 - 973 total spores $/ \mathrm{m}^{3}$. For all samples collected, 108 types of mold were found. The primary species of mold was: Aspergillus/Penicillium-like, which is generally associated with moisture issues. The contractor's professional recommendations were to enclose the server room (open to the mezzanine), replace water damaged ceiling tiles, and clean/inspect the HVAC units.

For Hotel B, the thermal comfort levels met the temperature set-point levels suggested by ASHRAE Standard 62.1-2004, but were near the upper limit for the relative humidity. The average ventilation rate generally met the ASHRAE 62.1-2004 Sections 4 - 7 guidelines, except for the front office area and the fitness room (which is kept at extreme temperatures for advanced yoga classes). ASHRAE 62-2004 recommends less than $1000 \mathrm{ppm} \mathrm{CO}_{2}$ in the indoor air environment, because human discomfort begins at levels above $800-1000 \mathrm{ppm}$. The carbon dioxide levels indoors at Hotel B are generally at the upper boundaries of the limit, particularly in the executive office suite and the spa/yoga/salon areas, which were not originally designed for the current usage of the space.

\subsection{Communications Practices}

Each hotel was charged with assembling a "Green Book" of current sustainability practices to be made available upon request. Placards, survey instruments, and signage were developed for letting guests know about the environmental initiatives at each hotel. Training materials were developed, the new employee orientation manual was updated, and technical memos with new environmental implementation policies (i.e. Energy Star replacement, anti-idling, recycling, etc.) and practices were developed in support of the program. Staff members and line employees were made familiar with the hotel's new environmental policies by conducting continuous improvement training sessions offered in three languages (English, Spanish, and Creole). Minutes of Green Team meetings were recorded and stored electronically in the Green Book, and a suggestion box (one for employees and one for guests) was made available to document feedback and provide a mechanism to nominate a "green" employee of the month, as part of a property-level incentive program.

To help target the areas of highest priority for sustainability initiatives, the manager on duty (MOD) logs were investigated to gain insight from the hotel guest's perspective. Among the most common guest complaints documented were: air conditioning issues, leaky faucets, hot water issues, shuttle bus breaking down, odors, pests and rodents, unsightly waste issues, and grease trap overflows. To assist in this process, the research team conducted surveys of hotel staff from both properties to determine a ranking of which sustainability initiatives were more important on a scale of $1-5$, with 5 being highest. Preliminary results from this study indicate that communication may be one of the most important areas of focus during the initial phases of implementation (Figure 2). 

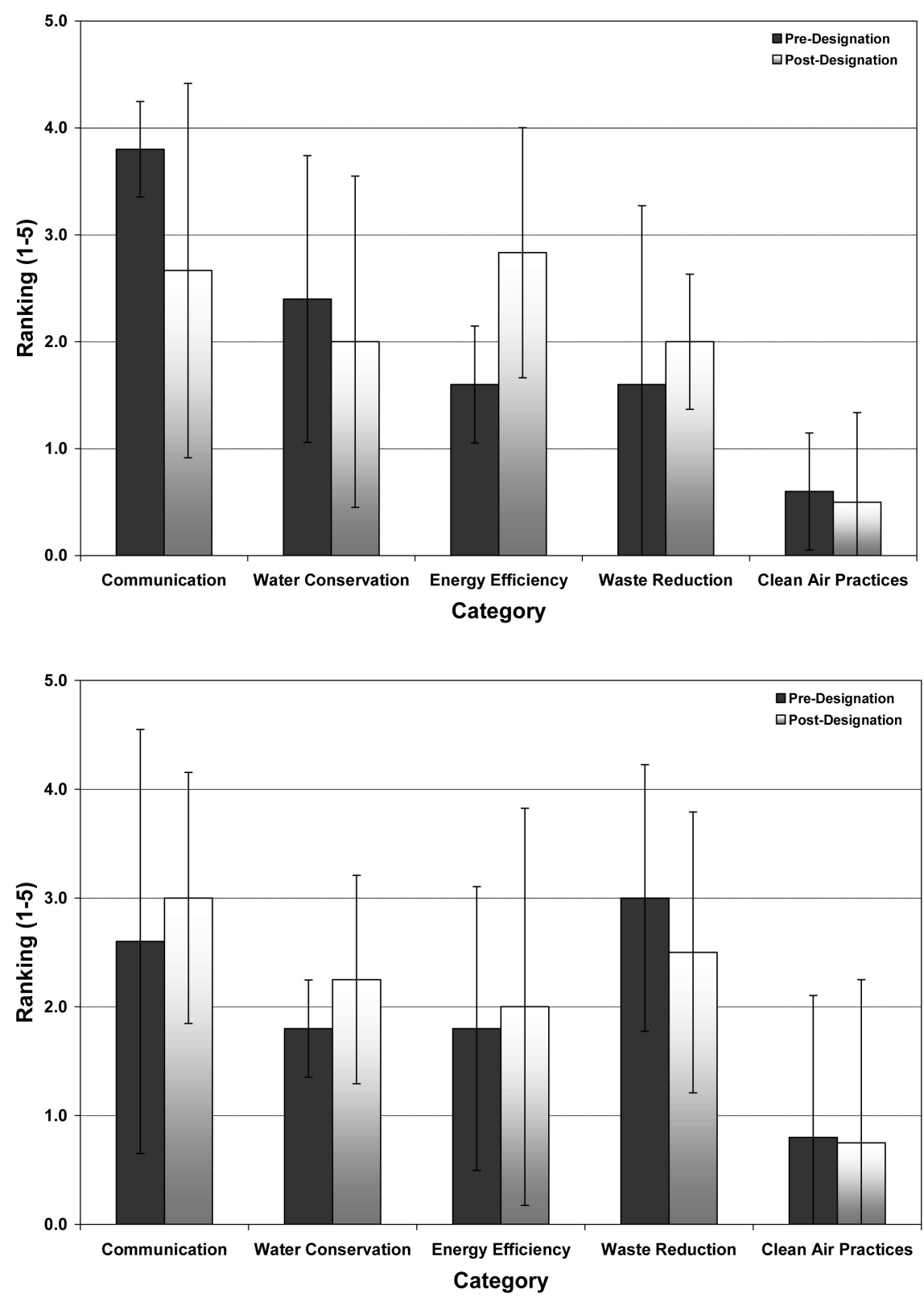

Figure 2. Results of ranking the sustainability initiatives during the pre-implementation and post-implementation interviews of hotel personnel for Hotel A (top) and Hotel B (bottom).

Waste reduction, because of lack of space for waste storage and its visibility to guests, was also considered a high priority. On the other hand, it was interesting to note that clean air seemed to consistently hold the lowest priority level for hotel staff.

\section{Conclusion}

In gathering all of the results from implementation and monitoring, the research team identified the sustainability initiatives that will likely make the most impact for similar hotels. Similar to those suggested by Jackson (2013) when investigat- 
ing other hotels, these include: 1) installation of computerized energy management systems to track and control electricity consumption in the guest rooms, back of the house, and common areas, 2) high efficiency lighting for all areas of the property, 3) recycling and composting, 4) thermal comfort systems to have more control of temperature and humidity set-backs, 5) sub-metering to reduce sewer charges for items such as irrigation systems, cooling towers and pools, 6) renewable energy options for water heating or back-up power applications, 7) building re-commissioning to improve the performance of the building as it was designed to operate, 8 ) switching to green cleaners, products, and finishes, 9) water use efficiency practices (i.e. sub-metering, fixture retrofits for faucets, showerheads, and toilets, cooling tower water treatment, etc.), 10) product substitution (i.e. reusable items, recyclable items, or items containing post-consumer recycled content), 11) eliminating environmental tobacco smoke at the facility, and 12) performance contracting to help finance implementation projects through forecasted savings and limit upfront capital expenditures.

It is important to note that the findings of this study are heavily influenced by the coastal, barrier-island location (Miami Beach, FL) that includes unique considerations (historical preservation issues, stringent hurricane building codes, etc.) and type of the participating hotels (boutique-style). Results are likely to vary according to differences in amenities/services provided, location, size, number of rooms, local conditions, management structure, etc. Therefore, the findings reported herein may not be completely representative of typical hotels in other locations.

In looking to the future, the participating hotels are investigating the possibility of implementing several new projects. They plan to do the following:

- Conduct more audits/assessments for energy, water, and indoor air quality;

- Re-evaluate existing funded projects (ex. chiller, roof, plumbing renovations, etc.) and look at more sustainable alternatives;

- Continue staff training;

- Create "allergy-friendly" rooms;

- Increase signage to market sustainability initiatives to guests and staff;

- Switch to no-VOC finishes and donate old materials to organizations such as Habitat for Humanity;

- Donate used/spent items to reduce space requirements for storage;

- Switch to eco-friendly water treatment chemicals for cooling towers;

- Investigate ozone laundry systems, dual flush toilets, low-flow showerheads, kitchen hood demand control ventilation, programmable thermostats, weather-stripping and insulation, dispensers for toiletries/amenities, pre-rinse dishwasher upgrades, and air-cooled ice machines;

- Install more sub-metering/monitoring;

- Switch out heat pump units to more energy efficient air conditioning systems;

- Expand guest recycling services;

- Implement leak detection programs; 
- Install occupancy/motion sensor lighting in conjunction with energy management systems;

- Expand use of "Green" cleaners for housekeeping;

- Initiate a composting program;

- Abolish bottled water use.

Both participating hotels have been plagued with a host of obstacles to overcome, such as high turnover rates, and lack of technical knowledge/expertise, communication issues, shortage of resources (time, money, incentives, etc.), permitting issues (historical preservation code and certificate of occupancy), a perceived lack of support from upper management, and finally "green" fatigue. Increased levels of communication would have mitigated many of these challenges and resulted in better performance, faster response times, greater participation, and less barriers to implementation. Probably the most important item to counteract these barriers would be to obtain a clear directive or a corporate-level mandate in writing prior to initiating any sustainability initiatives. This document should specifically pledge staff time and funding levels, while clearly establishing a hierarchy, a process for approval of sustainability projects, and granting local autonomy to make on-site decisions and approve expenditures. Another key item would be to make certain that sustainability initiatives are adequately represented in the annual budgeting process, with detailed cost analyses and official quotes from participating vendors. Vendors can often provide detailed estimates of potential savings, which can also be included to conduct the cost-benefit analysis.

At the same time, throughout the study, hotel personnel that were engaged in the process encountered resistance from corporate and managing supervisors because of high turnover, low priority, disinterest, certificate of occupancy issues, and economic/corporate pressures, but these were largely overcome by the time the designation visit was completed; replaced by a sense of accomplishment. There were palpable regrets about the inability to implement certain energy conserving strategies because of budgetary constraints and low priority assigned to energy management systems. Instead, management chose to address indoor air quality concerns, which had the unfortunate side effect of increasing energy costs.

This led to another important question that often came up "Who can grant approval if the guest experience is affected?" and "What is the incentive for line staff?" These issues must be addressed up front to better seize new opportunities. For instance, emergencies such as routine breakdowns, or even large capital expenditures that have been planned for years should be re-evaluated for potentially upgrading to more efficient options. Finally, it is imperative that each department in the hotel hierarchy have adequate representation in the Green Team, and alternates should be assigned to increase attendance and maintain adequate lines of communication based on consensus decisions made by the hotel community working together.

At the completion of the study, the hotel staff members were queried again 
about priorities. For Hotel A, the communications piece, which held the highest importance in the pre-designation survey, was replaced by energy efficiency as the most important issue to tackle (see Figure 2). Interestingly, as with the previous survey, clean air again held the lowest importance, this is likely because of the difficulty in directly measuring the short-term benefits of indoor environmental quality in terms of dollar savings. With Hotel B, the post-designation ranking mirrored the pre-designation responses quite closely. Waste reduction and communication were the dominant issues. The vacuum of well-defined, effective leadership contributed to the communication piece holding a high ranking throughout the study, and the recently conducted waste audits and space issues probably served to highlight the waste reduction piece for every employee surveyed. At the low end of the spectrum, indoor air quality remained the lowest priority, since Hotel B is an open air facility more like a motel configuration with outdoor amenities, the capability of going outside contributes to lowering the importance of indoor air quality.

\section{Acknowledgements}

The authors would like to thank the Florida Department of Environmental Protection for funding this work. We also thank the Palm Beach County Health Department, the management and staff of the participating hotels, and the various vendors that provided products and services during this project.

\section{Conflicts of Interest}

The authors declare no conflicts of interest regarding the publication of this paper.

\section{References}

Abt Associates Inc. (2001). A Method for Quantifying Environmental Indicators of Selected Leisure Activities in the United States. EPA-231-R-00-001, Washington DC: US Environmental Protection Agency.

Chan, W. (2005). Predicting and Saving the Consumption of Electricity in Sub-Tropical Hotels. International Journal of Contemporary Hospitality Management, 17, 228-237. https://doi.org/10.1108/09596110510591918

Chen, J. S., Sloan, P., \& Legrand, W. (2009). Sustainability in the Hospitality Industry. Maryland Heights, MO: Elsevier.

DeOreo, W. B., Mayer, P. W., Dziegielewski, B., \& Kiefer, J. (2016). Residential End Uses of Water, Version 2. Denver, CO: Water Research Foundation.

Energy Information Administration (2017). Electricity Consumption by Size and Type of Lodging Building: 2012 Building Data. https://www.eia.gov/consumption/commercial

Florida Department of Business and Professional Regulation (2019). Division of Hotels and Restaurants Annual Report 2017-2018.

http://www.myfloridalicense.com/dbpr/hr/reports/annualreports/documents/ar2018 1 9.pdf

Florida Department of Environmental Protection FDEP (2010). 2010 Solid Waste Annual Report Data, Table $1 A$. 
http://www.dep.state.fl.us/waste/categories/recycling/SWreportdata/10 data.htm

Graci, S., \& Dodds, R. (2008). Why Go Green? The Business Case for Environmental Commitment in the Canadian Hotel Industry. Anatolia, 19, 251-270. https://doi.org/10.1080/13032917.2008.9687072

Ham, S., \& Han, H. (2013). Role of Perceived Fit with Hotels' Green Practices in the Formation of Customer Loyalty: Impact of Environmental Concerns. Asia Pacific Journal of Tourism Research, 18, 731-748. https://doi.org/10.1080/10941665.2012.695291

Han, H. (2015). Travelers' Pro-Environmental Behavior in a Green Lodging Context: Converging Value-Belief-Norm Theory and the Theory of Planned Behavior. Tourism Management, 47, 164-177. https://doi.org/10.1016/j.tourman.2014.09.014 http://www.sciencedirect.com/science/article/pii/S0261517714001848

Han, H., \& Kim, Y. (2010). An Investigation of Green Hotel Customers' Decision Formation: Developing an Extended Model of the Theory of Planned Behavior. International Journal of Hospitality Management, 29, 659-668.

Han, H., Hsu, L., Lee, J., Lee, C., \& Sheu, C. (2011). Are Lodging Customers Ready to Go Green? An Examination of Attitudes, Demographics, and Eco-Friendly Intentions. International Journal of Hospitality Management, 30, 345-355.

https://doi.org/10.1016/j.ijhm.2010.07.008

Jackson, L. A. (2013). Best Management Practices in Green Lodging Defined and Explained. Hospitality Review, 31, Article 3.

https://digitalcommons.fiu.edu/hospitalityreview/vol31/iss1/3

Jones, P., \& Hillier, D. (2014). Comfort Sustainability in the Global Hotel Industry. International Journal of Contemporary Hospitality Management, 26, 5-17. https://doi.org/10.1108/IJCHM-10-2012-0180

Manaktola, K., \& Jauhari, V. (2007). Exploring Consumer Attitude and Behavior towards Green Practices in the Lodging Industry in India. International Journal of Contemporary Hospitality Management, 19, 364-377. https://doi.org/10.1108/09596110710757534

Meeroff, D. E., \& Scarlatos, P. D. (2007). Green Lodging Project Phase 2: Energy Efficiency and Clean Air Practices. Tallahassee, FL: Florida Department of Environmental Protection.

Meeroff, D. M., \& Scarlatos, P. D. (2008). Green Lodging Project Phase 4: Green Lodging Performance Measures: Implementation and Monitoring. Progress Report: Action Plan Implementation Update. Tallahassee, FL: Florida Department of Environmental Protection.

Oxford Economics (2019). Economic Impact of the US Hotel Industry. https://www.ahla.com/oxford-economics-study-0

Pizam, A. (2009). Green Hotels: A Fad, Ploy or Fact of Life? International Journal of Hospitality Management, 28, 1. https://doi.org/10.1016/j.ijhm.2008.09.001

Pryce, A. (2001). Sustainability in the Hotel Industry. Travel \& Tourism Analyst, 6, 95-114.

Rahman, I., \& Reynolds, D. (2019). The Influence of Values and Attitudes on Green Consumer Behavior: A Conceptual Model of Green Hotel Patronage. International Journal of Hospitality \& Tourism Administration, 20, 47-74. https://doi.org/10.1080/15256480.2017.1359729

Scarinci, J., \& Myers, T. (2014). A Semantic Web Framework to Enable Sustainable Lodging Best Management Practices in the USA. Information Technology \& Tourism, 14, 291-315. https://doi.org/10.1007/s40558-014-0011-y 
Stipanuk, D. M. (2001). Energy Management in 2001 and Beyond: Operational Options that Reduce Use and Cost. Cornell Hotel and Restaurant Administration Quarterly, 42, 57-70. https://doi.org/10.1016/S0010-8804(01)81025-9

UN Environment Programme (2009). Common Carbon Metric for Measuring Energy Use \& Reporting Greenhouse Gas Emissions from Building Operations. Paris: United Nations Environment Programme, Sustainable Buildings and Climate Initiative. http://wedocs.unep.org/bitstream/handle/20.500.11822/7922/-Common\%20Carbon\%2 0Metric\%20for\%20Measuring\%20Energy\%20Use\%20and\%20Reporting\%20Greenhous e\%20Gas\%20Emissions\%20from\%20Building\%20Operations-20094112.pdf?sequence= 3\&isAllowed $=\mathrm{y}$

Vickers, A. (2001). Handbook of Water Use and Conservation. Amherst, MA: Water Plow Press.

Visit Florida (2019). 2017 Economic Impact of Tourism in Florida State-Level Tourism Performance, Rockport Analytics.

https://www.visitflorida.org/media/71465/2017-contribution-of-travel-tourism-to-the-f lorida-economy.pdf

Wei, W., Miao, L., \& Huang, Z. J. (2013). Customer Engagement Behaviors and Hotel Responses. International Journal of Hospitality Management, 33, 316-330.

World Travel and Tourism Council (2019). Travel \& Tourism Benchmarking Research Trends 2019: How Does Travel \& Tourism Compare to Other Sectors.

https://www.visitflorida.org/media/71465/2017-contribution-of-travel-tourism-to-the-f lorida-economy.pdf 